\title{
Essential Oils from the Leaves and Flowers of Callistemon viminalis: Chemical Characterization and Evaluation of the Insecticide and Antifungal Activities
}

\author{
Thais Aparecida Sales ${ }^{1}$, Maria Das Graças Cardoso ${ }^{*}$, Luiz Gustavo De Lima Guimarães², \\ Karen Caroline Camargo', Danúbia Aparecida De Carvalho Selvati Rezende1, \\ Rafaela Magalhães Brandão1, Rafaela Vieira Souza1, Vanúzia Rodrigues Fernandes Ferreira1, \\ Ana Ermelinda Marques', Maísa Lamounier Magalhães ${ }^{3}$, David Lee Nelson ${ }^{4}$ \\ ${ }^{1}$ Department of Chemistry, Federal University of Lavras, Lavras, Brazil \\ ${ }^{2}$ Department of Natural Science, Federal University of São João Del Rei, São João Del Rei, Brazil \\ ${ }^{3}$ Department of Food Science, Federal University of Lavras, Lavras, Brazil \\ ${ }^{4}$ Pro-Reitoria de Pesquisa e Pós-Graduação, Federal University of the Jequitinhonha and Mucuri Valleys, Diamantina, Brazil \\ Email: *mcardoso@dqi.ufla.br
}

How to cite this paper: Sales, T.A., Cardoso, M.G., Guimarães, L.G.L., Camargo, K.C., Rezende, D.A.C.S., Brandão, R.M., Souza, R.V., Ferreira, V.R.F., Marques, A.E., Magalhães, M.L. and Nelson, D.L. (2017) Essential Oils from the Leaves and Flowers of Callistemon viminalis. Chemical Characterization and Evaluation of the Insecticide and Antifungal Activities. American Journal of Plant Sciences, 8, 2516-2529. https://doi.org/10.4236/ajps.2017.810171

\section{Received: July 28, 2017}

Accepted: September 19, 2017

Published: September 22, 2017

Copyright $\odot 2017$ by authors and Scientific Research Publishing Inc. This work is licensed under the Creative Commons Attribution International License (CC BY 4.0).

http://creativecommons.org/licenses/by/4.0/

\section{(c) (i) Open Access}

\begin{abstract}
The chemical compositions of the essential oils from the leaves and flowers of Callistemon viminalis and their insecticide and fungitoxic activities were determined. The essential oil was extracted by the hydrodistillation method using a modified Clevenger apparatus. The chemical characterization was performed by GC-MS and GC-FID. The evaluation of the insecticidal activity was performed with the Myzus persicae aphid, and the antifungal potential was determined via the inhibition of the mycelial growth of Alternaria alternata, Fusarium oxysorum and Botrytis cinérea phytopathogenic fungi. The principal components of the essential oils from the leaves and flowers were eucalyptol (84.60\% and 61.47\%), $\alpha$-pinene (10.28\% and $21.48 \%)$ and $\alpha$-terpineol $(2.59 \%$ and $2.79 \%$ ), respectively. The use of a $0.5 \%$ concentration of the essential oil from the flowers influenced the preference of aphids and their reproduction. The number of adult aphids decreased within a period of 48 hours in the presence of the essential oil from the leaves. In the test with no chance of choice, the mean number of adults decreased with both oils within 48 hours. No inhibition of the mycelial growth of the $A$. alternate microorganism was observed in any of the treatments with the two essential oils. However, the growth of $F$. oxysporum and $B$. cinerea fungi was inhibited. The mycelial growth of $F$. oxysporum was inhibited with the concentration of $100 \mu \mathrm{L} \cdot \mathrm{L}^{-1}$ of the oil from the flowers and $250 \mu \mathrm{L} \cdot \mathrm{L}^{-1}$ of the oil from the leaves. The inhibi-
\end{abstract}


tion of the growth of $B$. cinerea was observed at concentrations of 500 and 100 $\mu \mathrm{L} \cdot \mathrm{L}^{-1}$ for the oils from the flowers and leaves, respectively. The essential oils presented insecticidal and antifungal potentials. However, further studies are needed for these oils to be used in integrated pest management.

\section{Keywords}

Myzus persicae, Biological Activity, Phytopathogenic Fungi, Natural Products

\section{Introduction}

The Myzus persicae Sulzer aphid (Hemiptera: Aphididae), known as the peach aphid, is considered to be one of the most harmful species from an agricultural point of view, affecting several vegetable crops of great commercial importance. In addition, it is the most important vector of Potato Leafroll Virus (PLRV) in potato crops. This aphid causes direct damage through the continuous suction of the sap from the plant and indirect damage via transmission of the virus. It is the vector of more than 120 plant diseases [1]. In addition to insect attacks, various plant cultures are affected by phytopathogenic microorganisms, of which fungi occupy a prominent place because they are the principal cause of diseases in plants. Their action results in significant losses in production, as well as damage to grains during storage, reduction of nutritional value and even the production of mycotoxins harmful to humans and animals [2] [3].

For many years, the most widely used pest control method has been and still is the systematic spraying with synthetic pesticides. However, the indiscriminate use of these compounds has been limited because, in addition to possessing carcinogenic and teratogenic properties and causing damage to the environment, incorrect handling can lead to the resistance of these pests. Thus, products of natural origin, which have effects similar to those of the synthetic compounds used and which are more selective and less aggressive, have become increasingly important so that these products can be associated with the compounds already used for this purpose or even replace them.

The biological properties of many natural products have been the target of several studies, and they have shown promising results that enable their use as an alternative to products of synthetic origin. Among the products of natural origin are the essential oils, which are secondary metabolites produced by plants and are complex mixtures of low molecular weight, odoriferous and lipophilic substances that consist mainly of terpenoid compounds (mono- and sesquiterpenes) and phenylpropanoids [4]. Essential oils have many applications in pharmaceutical compounds, in the cosmetics industry, and agronomy, among others [5].

Brazil has a large variety of flora, which facilitates the study of the biological properties of the species that compose it. Callistemon viminalis, popularly known as bottle brush, is an ornamental plant belonging to the Myrtaceae Fami- 
ly. It is found in different localities, except in environments with a cold and dry climate [6]. The essential oil from this species can be found in both the flowers and the leaves, and there are studies that demonstrate antibacterial, allelopathic, and antioxidant activities for the essential oil from the leaves [7] [8]. However, there are no studies that report the biological potential of the essential oil from the flowers. The objective of this work was to characterize the essential oils from the leaves and flowers of Callistemon viminalis, as well as to evaluate their insecticidal activities against Myzus persicae and their fungitoxic activities against Fusarium oxysporum, Botrytis cinerea and Alternaria alternata phytopathogenic fungi.

\section{Material and Methods}

\subsection{Collection of Plant Material}

The leaves and flowers of $C$. viminalis were collected at the Campus of the Federal University of Lavras (UFLA), in Lavras, MG, Brazil, in September 2014, in the morning and with no precipitation at the following coordinates, latitude $21^{\circ} 14^{\prime} \mathrm{S}$, longitude $45^{\circ} 00^{\prime} \mathrm{W} \mathrm{Gr}$ and altitude of $918 \mathrm{~m}$. The species was identified in the Department of Biology of the Federal University of Lavras, and its exsicata was deposited in the ESAL Herbarium of the Federal University of Lavras with registration number 26,624 .

\subsection{Extraction of Essential Oils}

The essential oils were extracted by the hydrodistillation technique using a modified Clevenger apparatus. The extraction was performed over a period of two hours at $\pm 98^{\circ} \mathrm{C}$ [9]. After extraction, the hydrolates from both oils were centrifuged at $965 \mathrm{~g}$ for $5 \mathrm{~min}$ at room temperature using a bench top centrifuge. The oils were removed with the aid of a Pasteur pipette, packed in a glass vial, protected from moisture and light and stored at $4^{\circ} \mathrm{C}$. Simultaneously, the moisture content was determined [10]. The yield was calculated and expressed as mass of oil per mass of plant material on a moisture free basis $(\% \mathrm{~m} / \mathrm{m}$ in MFB).

\subsection{Chemical Characterization}

The constituents of the essential oils were identified using a gas chromatograph coupled to a mass spectrometer (GC/MS-Shimadzu, model QP 5050A) under the following experimental conditions: fused silica capillary column $(30 \mathrm{~m} \times 0.25$ $\mathrm{mm})$ with a bound DB5 phase $(0.25 \mu \mathrm{m}$ film thickness); He was the carrier gas with a flow rate of $1.0 \mathrm{~mL} \cdot \mathrm{min}^{-1}$; the temperature was programmed, starting at $60^{\circ} \mathrm{C}$, followed by an increase of $3^{\circ} \mathrm{C} \min ^{-1}$ to $240^{\circ} \mathrm{C}$, and then $10^{\circ} \mathrm{C} \mathrm{min}^{-1}$ to $300^{\circ} \mathrm{C}$, where the temperature was maintained for $7 \mathrm{~min}$. The injector temperature was $220^{\circ} \mathrm{C}$, and the detector (or interface) temperature was $240^{\circ} \mathrm{C}$; the volume of the sample injected was $0.5 \mu$, diluted in hexane; the split ratio was 1:100, and the column pressure was $71.0 \mathrm{kPa}$. 
The conditions of the mass spectrometer were the following: scanning detector, 1000; scanning interval of 0.50 fragments and fragments detected in the range of 45 to $500 \mathrm{Da}$. A series of linear hydrocarbon patterns $\left(\mathrm{nC}_{8}-\mathrm{nC}_{18}\right)$ was injected under the same conditions as those of the sample, and the Van den Dool and Kratz equation was used to calculate the retention index [11]. For the identification of the compounds, the spectra were compared with the NIST107 and NIST21 library databases, and the retention index, calculated for each constituent, was compared with the tabulated values [12].

The quantitative evaluation was performed by means of normalization of area (\%) using a Shimadzu CG-17A gas chromatograph equipped with a flame ionization detector (DIC) and the same operating conditions as those used in the identification of the components. The detector temperature was $280^{\circ} \mathrm{C}$.

\subsection{Insecticidal Activity}

The non-preference test of the Myzus persicae aphid was used for the evaluation of the insecticidal activity employing tomatoes treated with essential oils. The tests were performed with and without the opportunity for choice [1]. Tomato planting was accomplished using pots with a capacity of $1 \mathrm{~kg}$ of soil where the tomato seeds of the Santa Clara cultivar were planted. The aphids were collected in the field. They were brought to the laboratory and raised in cages with "Joá de capote" (Nicandra physaloides) in an environmental chamber at $25^{\circ} \mathrm{C} \pm 2{ }^{\circ} \mathrm{C}$ and a 12-hour photoperiod. For the trials, adult aphids of uniform size were chosen.

The tomato leaves were separated, and sections were cut with the aid of a circular plastic cutter $4 \mathrm{~cm}$ in diameter. These sections were sprayed with the samples in the abaxial part to the point of total drainage and fixed in Petri dishes on a $25 \mathrm{~mL}$ layer consisting of $1.0 \%$ agar. The plates were covered with PVC film punched with a pin. The treatments used were T1-water with Tween 80; T2-0.1\% essential oil; T3-0.5\% essential oil.

For the test with choice, each Petri dish contained a leaf section from each of the three treatments arranged in a circle to form an arena. In the center of each plaque, 15 adult and aphtero aphids (M. persicae) were released. In the test with no chance of choice, each Petri dish contained a leaf section from each treatment located in the center of the plate. Five $M$. persicae adults were released. The plates were maintained in the climatic chamber at $25^{\circ} \mathrm{C} \pm 2^{\circ} \mathrm{C}$ with a 12 -hour photophase. The evaluations were performed 24,48 and 72 hours after the release of the aphids by counting the number of aphids and nymphs on each leaf section.

The data were submitted to analysis of variance, $\sqrt{ }(x+0.5)$ transformed, with plots subdivided in time, and the means were compared by the Tukey test at the $5 \%$ probability level. The experimental designs were a completely randomized block design (CRBD) and a completely randomized design (CRD), with ten replications, for tests with and without a choice, respectively. The statistical program used was SISVAR [13]. 


\subsection{Evaluation of the Antifungal Activity of Essential Oils}

The study of fungitoxic activity of the essential oils was performed in the Laboratory of Mycology of the Department of Phytopathology of the Federal University of Lavras. Fusarium oxysporum, Botrytis cinerea and Alternaria alternata were obtained from the department's library. To evaluate the antifungal potential of the essential oils, the modified Agar Dilution method [14] was used. Initially, a stock solution $\left(40,000 \mu \mathrm{L} \cdot \mathrm{L}^{-1}\right)$ of the essential oils was prepared in an aqueous solution containing $0.1 \%$ Tween 80 . From this solution, specific aliquots were pipetted and incorporated into the Malt/Agar culture medium to furnish the final concentrations of $100,250,500,750$ and $1000 \mu \mathrm{L} \cdot \mathrm{L}^{-1}$. The mixtures were then poured into 5-cm-diameter Petri dishes. After solidification of the medium, 4-mm-diameter discs were removed from pure cultures of each fungus and place on the center of each plate. Together with the treatments, relative controls containing water/Tween 80 solution and an absolute control consisting only of the Malt/Agar medium were prepared. For each treatment and for each control, four replications were performed. When the mycelial growth of the absolute controls reached the edge of the plates, diametrically opposite measurements were made of the mycelial growth of the other samples. The results were expressed as percent inhibition of mycelial growth.

\section{Results and Discussion}

The moisture contents of the leaves and flowers of $C$. viminalis were $47 \%$ and $20.6 \%$, respectively. The essential oil content of the leaves was $1.14 \%$, and that of the flowers was $0.092 \%$. Studies carried out with plants of this same species collected in Brazil and in other countries resulted in lower yields of essential oil from the leaves than that observed in this work. Srivastava et al. [15] evaluated the essential oil from the leaves of $C$. Viminalis collected in India and obtained a yield of $0.45 \%$. Oyedeji et al. [16] found $0.90 \%$ of the essential oil in leaves of plants collected in South Africa. In Brazil, Silva et al. [17] studied the essential oil from $C$. viminalis and obtained a yield of $0.3 \%$. However, the essential oil content found in flowers was lower than that reported by Pires et al. [18], who observed a content of $0.30 \%$ of essential oil in fresh flowers, and by Oliveira et al. [7], who reported a yield of $0.24 \%$ on a moisture-free basis. According to Gobbo-Neto and Lopes [19], these variations can be attributed to differences in seasonality, temperature, and soil type, among others. However, all the studies have shown that the yield of the essential oil from the leaves is greater than that from the flowers.

The compounds identified in the essential oils of the leaves and flowers of $C$. viminalis, together with the calculated retention indices and contents expressed as percentage are shown in Table 1 . The principal compounds of the essential oils in the leaves and flowers were eucalyptol (leaves, $84.60 \%$; flowers, $61.47 \%$ ), followed by $\alpha$-pinene (leaves, $10.28 \%$; flowers, $21.48 \%$ ) and $\alpha$-terpineol (leaves, 2.59\%; flowers, 2.79\%). Figure 1 and Figure 2 correspond to the chromatograms of the essential oils of flowers and leaves of Callistemon viminalis. 
Table 1. Chemical composition of the essential oils from the leaves and flowers of $C$. viminalis.

\begin{tabular}{|c|c|c|c|}
\hline \multirow{2}{*}{ Compound } & \multicolumn{3}{|c|}{ Composition (\%) } \\
\hline & ${ }^{\star}$ RIcal & Flowers & Leaves \\
\hline$\alpha$-Pinene & 907 & 21.48 & 10.28 \\
\hline$\beta$-Pinene & 923 & 0.36 & 0.64 \\
\hline Myrcene & 926 & - & 0.20 \\
\hline p-Cymene & 1000 & 1.05 & 0.45 \\
\hline Eucalyptol & 1003 & 61.47 & 84.60 \\
\hline$\gamma$-Terpinene & 1010 & 0.56 & 0.24 \\
\hline$\alpha$-Terpinene & 1019 & 0.26 & - \\
\hline Linalool & 1088 & 0.55 & 0.20 \\
\hline$\alpha$-Fenchol & 1094 & 0.33 & - \\
\hline Isoborneol & 1108 & 0.40 & - \\
\hline Terpinen-4-ol & 1110 & 0.85 & 0.59 \\
\hline$\alpha$-Terpineol & 1114 & 2.79 & 2.59 \\
\hline Viridiflorol & 1479 & 0.90 & - \\
\hline Spathulenol & 1481 & 2.27 & - \\
\hline$\beta$-Selinene & 1482 & 1.50 & - \\
\hline$\alpha$-Elemol & 1483 & 1.80 & - \\
\hline$\beta$-Eudesmol & 1486 & 0.61 & - \\
\hline$\%$ Identification & & 97.18 & 99.79 \\
\hline
\end{tabular}

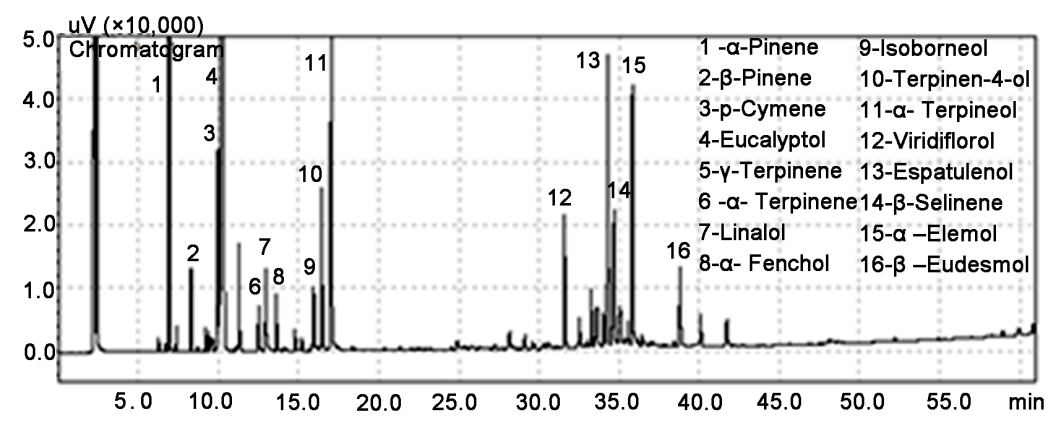

Figure 1. Chromatogram of the essential oil of $C$. viminalis flowers.

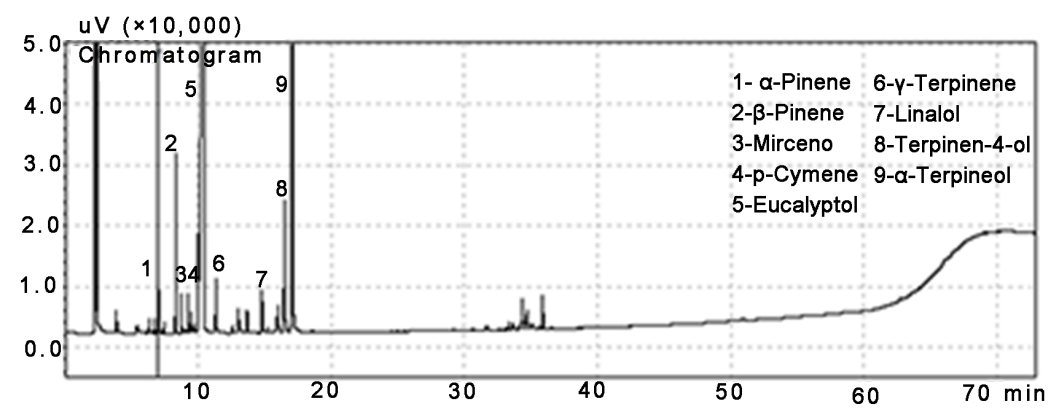

Figure 2. Chromatogram of the essential oil of $C$. viminalis leaves. 
The principal components of both essential oils (Table 1) are the same. However, their percentages are different, in addition to the fact that the flower oil has a higher percentage of minor compounds than the essential oil from the leaf. The appearance of new organs in the plant, as is the case with blossoming, increases the biomass of the plant and the concentration of metabolites may decrease because they can be redistributed by the plant. In addition, the leaves and flowers are located in different parts of the plant and might undergo different types of stress, which might influence the essential oil content [20].

Pires et al. [18] analyzed the chemical composition of the essential oils from fresh leaves, dried leaves and flowers of $C$. viminalis and found eucalyptol (fresh leaves, $70.43 \%$; dry leaves, $71.71 \%$; flowers, $42.39 \%$ ) to be the principal component, followed by tricyclene (fresh leaves, 12.97\%; dry leaves, 8.20\%; flowers, $28.08 \%)$. Previously, Quijano-Celis et al. [20] observed that eucalyptol (39.4\%), $\alpha$-pinene (8.9\%), $\alpha$-phellandrene (8.6\%) and $\alpha$-terpineol (6.1\%) were the principal components. Shreeya et al. [21] also observed that 1,8-cineole and $\alpha$-pinene, the main monoterpenes, were the principal components of this oil.

Eucalyptol was found to be the principal compound by all the authors, data that corroborate those observed in the present study. However, there is a variation in the other components. As already mentioned, the production of secondary metabolites can be influenced by several factors, and quantitative and qualitative variations in the contents of essential oils are associated with genetic, environmental and physiological demands, such as growth, reproduction and defensive mechanisms of the plant.

The results of the assays for insecticidal activity of the essential oils are described in the tables below. In the test with an opportunity for choice (Table 2), the preference of the adult aphids in the sections, or their reproduction, was not influenced by the different concentrations of the essential oil from the leaves of $C$. viminalis. There was no statistical variation in the number of adults and nymphs in each treatment relative to the control. The average number of adult aphids present in the treatment with the essential oil from the flowers in the concentration of $0.5 \%$ was statistically different and smaller than that of the control, showing that the insects had a greater preference for the control section. In addition, the reproduction of aphids was influenced by the $0.5 \%$ concentration of the essential oil from $C$. viminalis flowers. The number of nymphs present in the leaf section with this treatment was lower than those observed in the treatment with $0.1 \%$ of the essential oil and the control.

The effect of the essential oils from the leaves and flowers of $C$. viminalis on the number of $M$. persicae adults and nymphs as a function of time (hours) is described in Table 3. The essential oil from the leaves (Table 2) interfered with the preference of aphids when they had contact with the oil during a period of 48 hours. There was a decrease in the number of adults after this period. The mean was statistically lower than that observed after 24 hours. The application of leaf oil did not favor the reproduction of the aphids until the time of 42 hours, after which there was an increase in the mean number of nymphs. The means observed 
Table 2. Mean values for the number of adults and nymphs of Myzus persicae in the test of non-preference with choice as a function of concentrations of the essential oils from the leaves and flowers of Callistemon viminalis.

\begin{tabular}{ccccc}
\hline \multirow{2}{*}{ Concentration (\%) } & \multicolumn{2}{c}{ Number of live adults } & \multicolumn{2}{c}{ Number of nymphs } \\
\cline { 2 - 5 } & Leaves & Flowers & Leaves & Flowers \\
\hline 0 & $2.12 \mathrm{a}$ & $2.0 \mathrm{c}$ & $2.04 \mathrm{~d}$ & $2.14 \mathrm{e}$ \\
0.1 & $1.52 \mathrm{a}$ & $1.73 \mathrm{bc}$ & $1.49 \mathrm{~d}$ & $1.52 \mathrm{e}$ \\
0.5 & $1.73 \mathrm{a}$ & $0.97 \mathrm{~b}$ & $1.36 \mathrm{~d}$ & $0.65 \mathrm{f}$ \\
\hline
\end{tabular}

Means followed by the same letter in a column do not differ statiscally by the Tukey test at a level of $5 \%$ of probability.

Table 3. Mean values for the number of Myzus persicae adults and nymphs in the non-preference with choice test as a function of the variation of the contact time of the insects with the leaves treated with the essential oils from the leaves and flowers of Callistemon viminalis.

\begin{tabular}{|c|c|c|c|c|}
\hline \multirow{2}{*}{ Time interval (h) } & \multicolumn{2}{|c|}{ Number of live adults } & \multicolumn{2}{|c|}{ Number of nymphs } \\
\hline & Leaves & Flowers & Leaves & Flowers \\
\hline & $1.89 \mathrm{a}$ & $1.62 \mathrm{c}$ & $1.22 \mathrm{a}$ & $1.38 \mathrm{c}$ \\
\hline 48 & $1.72 \mathrm{~b}$ & $1.53 \mathrm{c}$ & $1.49 \mathrm{a}$ & $1.54 \mathrm{c}$ \\
\hline 72 & $1.77 \mathrm{ab}$ & $1.64 c$ & $2.17 b$ & $1.40 \mathrm{c}$ \\
\hline
\end{tabular}

The means followed by the same letter in the column do not differ statistically from one another by the Tukey test at the $5 \%$ probability level.

with the essential oil from the flowers remained constant over time, indicating that it had no influence on the preference of the adults for the leaf sections or their reproduction. The activity related to the oil from the flowers remained independent of the variation in time at the concentration of $0.5 \%$, whereas it did not remain constant at the concentration of $0.1 \%$.

Some differences in the compositions of the essential oils from the leaves and flowers of $C$. viminalis exist; some of the minor compounds present in the essential oil from the flowers are not present in the essential oil from the leaves. In addition, the percentage of $\alpha$-pinene is higher in the essential oil from the flowers. These differences might be linked to the greater activity of the essential oil from the flowers. Although the principal components are the same, the minority compounds can potentiate the activity through synergism, or they might even be responsible for the differences in activity.

Regarding the no-choice test, which evaluated the toxicity of the essential oils, the essential oils from both the leaves and the flowers were not toxic to insects, regardless of the concentration used (Table 4). There was no statistical variation in the number of adults or nymphs in both treatments. Because the activity of the essential oil from the flowers in the test with a chance of choice varied with the concentration and no activity was observed in the test without choice, it can be inferred that the oil interferes in the preference and oviposition of M. persicae, but it is not toxic to the aphid. 
Table 4. Mean values for the number of Myzus persicae adults and nymphs present in leaf sections in the no preference test, with no chance of choice, as a function of the concentrations of the essential oils $(0.1 \%$ and $0.5 \%)$ from flowers and leaves of Callistemon viminalis.

\begin{tabular}{ccccc}
\hline \multirow{2}{*}{ Concentration (\%) } & \multicolumn{2}{c}{ Number of live adults } & \multicolumn{2}{c}{ Number of nymphs } \\
\cline { 2 - 5 } & Leaves & Flowers & Leaves & Flowers \\
\hline 0 & $1.66 \mathrm{a}$ & $1.70 \mathrm{~b}$ & $1.92 \mathrm{c}$ & $1.95 \mathrm{~d}$ \\
0.1 & $1.65 \mathrm{a}$ & $1.79 \mathrm{~b}$ & $1.84 \mathrm{c}$ & $2.12 \mathrm{~d}$ \\
0.5 & $1.64 \mathrm{a}$ & $1.59 \mathrm{~b}$ & $1.90 \mathrm{c}$ & $1.65 \mathrm{~d}$ \\
\hline
\end{tabular}

The effect of the contact time of the insects with the essential oils is presented in Table 5. At the 48-h interval, there was a difference in the mean number of adults present in the leaf sections for both oils. However, after this interval, no statistical difference in the mean number of aphids was observed. Thus, the interval of 48 hours is the optimum time for activity to be observed. Prior to this time, the essential oils were not toxic to adults. There was no significant difference in the mean number of nymphs between the treatments and the control for both the leaf oil and the flower oil when the concentrations of the oils were varied.

Zandi-Sohani et al. [22] evaluated the repellent and insecticidal activity of the essential oil from Callistemon citrinus (Myrtaceae) against adult Callosobruchus maculatus (F.) (Coleoptera: Bruchidae) males and found that the oil was toxic to adults in the fumigation test. The results varied according to the time of exposure of the insect to the oil. The $\mathrm{LD}_{50}$ values found were 12.88 and $84.4 \mu \mathrm{L} \cdot \mathrm{L}^{-1}$ for males and females, respectively. The essential oil from C. citrinus also had a repellent effect against $C$. macullatus. The principal components [1.8-cineol (34.2\%) and $\alpha$-pinene (29.0\%)] found in C. citrinus oil were the same as those of the essential oils analyzed in the present study, and it can be inferred that these compounds are related to the insecticidal activity of the essential oils from the $C$. viminalis leaves and flowers. The evaluation of contact toxicity of $C$. viminalis leaves against Acanthoscelides obtectus and Callosobruchus maculatus (Coleoptera: Bruchidae) adults were evaluated by Ndomo et al. [6]. The results obtained for the fumigation experiments showed that $C$. maculatus and A. obtectus were susceptible to essential oil vapors, and the $\mathrm{LC}_{50}$ values were $0.019 \mu \mathrm{L} \cdot \mathrm{cm}^{-3}$ and $0.011 \mu \mathrm{L} \cdot \mathrm{cm}^{-3}$, respectively, after $12 \mathrm{~h}$ of exposure. For the contact toxicity test, A. obtectus was more susceptible $\left(\mathrm{LD}_{50}=0.133 \mu \mathrm{L} \cdot \mathrm{g}^{-1}\right)$ than $C$. maculatus $\left(\mathrm{LD}_{50}=0.170 \mu \mathrm{L} \cdot \mathrm{g}^{-1}\right)$ after 2 days of exposure. The essential oil from the leaves of $C$. viminalis also exerted an effect against other insects and may, therefore, be further studied so that means for its use as an alternative in the control of pest insects can be developed.

With respect to the antifungal activity, the essential oils did not inhibit the mycelial growth of $A$. alternate because the percentage of mycelial growth of the microorganism in the samples containing the treatments was similar to that of the control. However, it did inhibit the growth of the other two fungi. The percentage 
Table 5. Mean numbers of Myzus persicae adults and nymphs present in the leaf sections in the no preference test, with no chance of choice, as a function of the contact time of the insects with the leaves treated with the essential oils from the flowers and leaves of Callistemon viminalis.

\begin{tabular}{ccccc}
\hline \multirow{2}{*}{ Time interval (h) } & \multicolumn{2}{c}{ Number of live adults } & \multicolumn{2}{c}{ Number of nymphs } \\
\cline { 2 - 5 } & Flowers & Leaves & Flowers & Leaves \\
\hline 24 & $1.77 \mathrm{a}$ & $1.82 \mathrm{c}$ & $1.93 \mathrm{e}$ & $1.95 \mathrm{f}$ \\
48 & $1.53 \mathrm{~b}$ & $1.54 \mathrm{~d}$ & $1.88 \mathrm{e}$ & $1.80 \mathrm{f}$ \\
72 & $1.63 \mathrm{ab}$ & $1.72 \mathrm{~cd}$ & $1.85 \mathrm{e}$ & $1.98 \mathrm{f}$ \\
\hline
\end{tabular}

The means followed by the same letter in the column do not differ statistically from one another by the Tukey test at the $5 \%$ probability level.

inhibition of mycelial growth of $F$. oxysporum by the essential oils from the leaves and flowers of $C$. viminallis is presented in Table 6 .

As can be seen, the mycelial growth of the microorganism in question was inhibited by the $100 \mu \mathrm{L} \cdot \mathrm{g}^{-1}$ concentration of the essential oil from the flowers. The inhibition caused by flower oil was almost twice that from the leaves. The essential oils were also able to inhibit the growth of $B$. cinerea, as shown in Table 7 .

The authors observed an in vitro inhibitory effect of $S$. molle essential oil on Alternaria spp., Fusarium spp., Collethotricum spp. and Botrytis spp., whereas the essential oil of $S$. terebinthifolius had a more pronounced fungicidal effect against Botrytis spp. The authors also address the complexity of the chemical composition of essential oils and the difficulties in assigning their biological activities to isolated compounds present in the oils, since interactions between the compounds may occur. In addition, the presence of constituents such as citral, pinene, eucalyptol, (E)-caryophyllene, $\beta$-elemene, furanodiene, limonene, eugenol and carvacrol may influence the biological activity of the oil.

Essential oils from both leaves and flowers of $C$. viminalis showed similar major compounds differing only in their percentages. In addition, some of the minor compounds were different. Both oils had an inhibitory effect against two of the three evaluated fungi, and repellent against the insect $M$. persicae, being more efficient in combating fungi. Thus, these can be considered as an alternative source of compounds possessing activity on insects and pest microorganisms. However, for these products to be marketed, it will be necessary to continue this work with new tests that make feasible the use of these in integrated pest management.

The essential oil from the leaves was the most efficient (Table 7), presenting a significantly higher inhibition. In general, the inhibition of the growth of $B$. $c i$ nerea by the leaf essential oil was greater. There are a multitude of factors that might be responsible for the differences in the activities of the two oils, such as the differences in chemical composition. As mentioned above, they contain the same principal compounds, but in different percentages. The less abundant 
Table 6. Percentage inhibition of mycelial growth of the Fusarium oxysporum fungus by the essential oils from the leaves and flowers of Callistemon viminalis.

\begin{tabular}{ccc}
\hline \multirow{2}{*}{ Concentration $\left(\mu \mathrm{L} \cdot \mathrm{L}^{-1}\right)$} & \multicolumn{2}{c}{ Inhibition (\%) } \\
\cline { 2 - 3 } & Leaves & Flowers \\
\hline 0 & 0.00 & 0.00 \\
100 & 0.00 & 0.53 \\
250 & 0.71 & 1.96 \\
500 & 2.14 & 4.46 \\
750 & 5.89 & 10.17 \\
1000 & 8.03 & 16.42
\end{tabular}

The means followed by the same letter in the column do not differ statistically from one another by the Tukey test at the $5 \%$ probability level.

Table 7. Percentage inhibition of mycelial growth of the Botrytis cinerea fungus by the essential oils from the leaves and flowers of Callistemon viminalis.

\begin{tabular}{ccc}
\hline & \multicolumn{2}{c}{ Inhibition (\%) } \\
\cline { 2 - 3 } Concentration $\left(\mu \mathrm{L} \cdot \mathrm{L}^{-1}\right)$ & Leaves & Flowers \\
\hline 0 & 0.00 & 0.00 \\
100 & 6.96 & 0.00 \\
250 & 10.53 & 0.00 \\
500 & 14.28 & 1.43 \\
750 & 15.17 & 9.10 \\
1000 & 21.24 & 11.07 \\
\hline
\end{tabular}

compounds are present in different concentrations. The mechanisms of action of the oils might not be the same because of the morphology of the fungus.

Because both oils had an inhibitory effect on the two fungi (B. cinerea and $\mathrm{F}$. oxysporum), with differences in the percentages of inhibition, it is assumed that the compound or compounds responsible for the inhibition of mycelial growth are present in the essential oils from both the leaves and the flowers in different percentages. However, the compounds responsible for the inhibition of fungal growth are not the same, because the essential oil from the flowers was more effective against $F$. Oxysporum, whereas the oil from the leaves presented greater activity against $B$. cinerea. Because of the chemical complexity of the essential oils, the activity cannot be attributed to any specific compound without further testing.

Many essential oils that have inhibitory activity against fungi and bacteria contain $\alpha$-pinene as a principal component, such as the essential oil from Rosmarinus officinalis, for which there are several reports in the literature regarding its activity against species of Candida. Freire et al. [23] evaluated the activity of 
the essential oil from $R$. officinalis against strains of the Candida albicans and Candida tropicalis fungi and observed that the inhibitory activity increased with the duration of exposure of the microorganisms to the oil.

The essential oils from Schinus molle L. and Schinus terebinthifolius were characterized by Santos et al. [2]. The oil from $S$. molle contained principally $\alpha$-pinene and sabinene, and the oil from $S$. terebinthifolius contained $\alpha$-pinene, sabinene and bicyclogermacrene. The authors observed an in vitro inhibitory effect of the essential oil from $S$. molle against Alternaria spp., Fusarium spp., Collethotricum spp. and Botrytis spp., whereas the essential oil from S. terebinthifolius presented a more pronounced fungicidal effect against Botrytis spp.

The authors also addressed the complexity of the chemical composition of essential oils and the difficulties in assigning their biological activities to isolated compounds present in the oils because interactions between the compounds can occur. In addition, the presence of constituents such as citral, pinene, eucalyptol, (E)-caryophyllene, $\beta$-elemene, furanodiene, limonene, eugenol and carvacrol might influence the biological activity of the oil.

\section{Conclusion}

Essential oils from both the leaves and flowers of $C$. viminalis contained similar principal compounds, differing only in their percentages. In addition, some of the compounds present in smaller amounts were different. Both oils exhibited an inhibitory effect against two of the three fungi evaluated and a repellent activity against the $M$. persicae, being more efficient in combating fungi. Thus, these oils can be considered to be alternative sources of compounds possessing activity against insects and microorganism pests. However, for these products to be marketed, it will be necessary to continue this work with new tests that make the use of these products in integrated pest management feasible.

\section{Acknowledgements}

The authors acknowledge the support of the Fundação de Amparo à Pesquisa do Estado de Minas Gerais (FAPEMIG), Conselho Nacional de Desenvolvimento Científico e Tecnológico (CNPq), and the Coordenaçåo de Aperfeiçoamento de Pessoal de Ensino Superior (CAPES).

\section{References}

[1] Teixeira, M.L., et al. (2014) Essential Oils from Lippia origanoides Kunth. and Mentha spicata L.: Chemical Composition, Insecticidal and Antioxidant Activities. American Journal of Plant Sciences, 5, 1181-1190. https://doi.org/10.4236/ajps.2014.59131

[2] Teixeira, M.L. (2010) Efeito fungicida dos óleos essenciais de Schinus molle L. e Schinus terebinthifolius Raddi, Anacardiaceae, do Rio Grande do Sul. [Fungicidal Effect of the Essential Oils from Schinus molle L. and Schinus terebinthifolius Raddi, Anacardiaceae, from Rio Grande do Sul.] Revista Brasileira de Farmacognosia, 154-159. 
[3] Teixeira, M.S., et al. (2012) Citrumelo swingle: Caracterização química, atividade antioxidante e antifúngica dos óleos essenciais das cascas frescas e secas. [Citrumelo swingle: Chemical Characterization, Antioxidant and Antifungal Activities of the Essential Oils from the Fresh and Dried Skins.] Magistra, Cruz das Almas-BA, 24, 194-203.

[4] Raut, J.S. and Karuppayil, S.M. (2014) A Status Review on the Medicinal Properties of Essential Oils. Industrial Crops and Products, 62, 250-264.

https://doi.org/10.1016/j.indcrop.2014.05.055

[5] Bizzo, H.R. Hovell, A.M.C. and Rezende, C.M. (2009) Óleos essenciais no Brasil: aspectos gerais, desenvolvimento e perspectivas. [Essential Oils in Brazil: General Aspects, Progress and Perspectives.] Química Nova, 32, 588-594. https://doi.org/10.1590/S0100-40422009000300005

[6] Ndomo, A.F., et al. (2010) Insecticidal Activities of Essential Oil of Callistemon viminalis Applied as Fumigant and Powder against Two Bruchids. Journal of Applied Entomology, 134, 333-341. https://doi.org/10.1111/j.1439-0418.2009.01475.x

[7] Oliveira, C.M., et al. (2014) Chemical Composition and Allelopathic Activity of the Essential Oil from Callistemon viminalis (Myrtaceae) Blossoms on Lettuce (Lactuca sativa L.) Seedlings. American Journal of Plant Sciences, 5, 3551-3557. https://doi.org/10.4236/ajps.2014.524371

[8] Salem, M.Z.M., et al. (2013) Evaluation of Extracts and Essential Oil from Callistemon Viminalis Leaves: Antibacterial and Antioxidant Activities, Total Phenolic and Flavonoid Contents. Asian Pacific Journal of Tropical Medicine, 2013, 785-791. https://doi.org/10.1016/S1995-7645(13)60139-X

[9] Brasil (2010) Agência Nacional de Vigilância Sanitária. Farmacopéia Brasileira. [Brazilian Pharmacopeae.] 5th Edition, Anvisa, Brasília, 198-199.

[10] Pimentel, F.A., et al. (2006) A Convenient Method for the Determination of Moisture in Aromatic Plants. Química Nova, 29, 373-375. https://doi.org/10.1590/S0100-40422006000200031

[11] Van den Dool, H. and Kratz, P.D. (1963) A Generalization of the Retention Index System Including Linear Temperature Programmed Gas-Liquid Partition Chromatography. Journal Chromatography A, 11, 463-471.

[12] Adams, R. (2007) Identification of Essential Oils Components by Gas Chromatography/Mass Spectroscopy. 4th Edition, Carol Stream, Allured, 804 p.

[13] Ferreira, D.F. (2011) Sisvar: A Computer Statistical Analysis System. Ciência e Agrotecnologia, 35, 1039-1042. https://doi.org/10.1590/S1413-70542011000600001

[14] Klančnik, A., Piskernik, S., Jeršek, B. and Možina, S.S. (2010) Evaluation of Diffusion and Dilution Methods to Determine the Antibacterial Activity of Plant Extracts. Journal of Microbiological Methods, 81, 121-126.

[15] Srivastava, S.K., et al. (2003) Essential Oil Composition of Callistemon viminalis Leaves from India. Flavour and Fragrance Journal, 18, 361-363.

[16] Oyedeji, O.O., et al. (2009) Chemical Composition and Antibacterial Activity of the Essential Oils of Callistemon citrinus and Callistemon viminalis from South Africa. Molecules, 14, 1990-1998. https://doi.org/10.3390/molecules14061990

[17] Silva, C.J., et al. (2010) Chemical Composition and Antibacterial Activities from the Essential Oils of Myrtaceae Species Planted in Brazil. Química Nova, 33, 104-108. https://doi.org/10.1590/S0100-40422010000100019

[18] Pires, C.H., et al. (2013) Composição química e atividade antimicrobiana dos óleos essenciais das folhas e flores de Callistemon viminalis (sol. ex Gaertn.) G. Don ex. 
Loudon (Myrtaceae). [Chemical Characterization and Antimicrobial Activity of the Essential Olis from the Leaves and Flowers of Callistemon viminalis (sol. ex Gaertn.) G. Don ex. Loudon (Myrtaceae).] Revista de Ciências Farmacêuticas Básica e Aplicada, 34, 597-601.

[19] Gobbo-Neto, L. and Lopes, N. (2007) Plantas Medicinais: Fatores de influência no conteúdo de metabólitos. [Medicinal Plants: Factors That Influence the Metabolite Concents.] Química Nova, 30, 374-381. https://doi.org/10.1590/S0100-40422007000200026

[20] Quijano-Celis, C. (2010) Chemical Composition and Antibacterial Activity of the Essential oil of Callistemon viminalis (Gaertn.) g. Don Leaves from Colombia. Journal of Essential Oil Bearing Plants, 13, 710-716. https://doi.org/10.1080/0972060X.2010.10643883

[21] Shreeya, A.B., et al. (2017) Chemical Characterization and Phytotoxicity of Foliar Volatiles and Essential Oil of Callistemon viminalis. Journal of Essential Oil Bearing Plants, 20, 535-545.

[22] Zandi-Sohani, N., Mhojjati and Carbonell-Barrachina, Á.A. (2013) Insecticidal and Repellent Activities of the Essential Oil of Callistemon citrinus (Myrtaceae) against Callosobruchusmaculatus (F.) (Coleoptera: Bruchidae). Neotropical Entomology, 42, 89-94. https://doi.org/10.1007/s13744-012-0087-z

[23] Freire, I.C.M. (2012) Atividade antifúngica do óleo essencial de Rosmarinus officinalis sobre a cinética do crescimento de Candida albicans e Candida tropicalis. [Antifungal Activity of the Essential Oil from Rosmarinus officinalis on the Growth Kinetics of Candida albicans and Candida tropicalis.] Revista Brasileira de Ciências da Saúde, 16, 343-346. https://doi.org/10.4034/RBCS.2012.16.03.10

\section{Scientific Research Publishing}

Submit or recommend next manuscript to SCIRP and we will provide best service for you:

Accepting pre-submission inquiries through Email, Facebook, LinkedIn, Twitter, etc. A wide selection of journals (inclusive of 9 subjects, more than 200 journals)

Providing 24-hour high-quality service

User-friendly online submission system

Fair and swift peer-review system

Efficient typesetting and proofreading procedure

Display of the result of downloads and visits, as well as the number of cited articles

Maximum dissemination of your research work

Submit your manuscript at: http://papersubmission.scirp.org/

Or contactajps@scirp.org 